\title{
ANALYSIS OF IRI VALUE FOR ASSESSMENT OF OPTIMUM MAINTENANCE STRATEGY FOR LOW TRAFFIC VOLUME ROADS IN NEPAL
}

\author{
Ramesh Bala ${ }^{1}$, Ghana Shyam Gautam², Gautam Bir Singh Tamrakar ${ }^{3}$ \\ ${ }^{1}$ Department of Civil Engineering, Khwopa College of Engineering, Libali-8, Bhaktapur, Nepal, \\ ${ }^{2}$ Department of Road, Ministry of Physical Planning and Work, Government of Nepal \\ ${ }^{3}$ Department of Civil Engineering, Institute of Engineering, Pulchowk Campus,
}

\begin{abstract}
:
Road infrastructure is an important sector of economic activity for the development of a country. The road infrastructure is required to be maintained in proper condition to ensure its continuous utilization in proper manner. By proper maintenance of roads, continuous acceptability, a higher economy, safety and serviceability are gained. This research work was carried out through analysis of data collected from Department of Road (DoR) Nepal and surveyed through Google Earth. While analyzing data, data are categorized according to road type and pavement surface with spatial coverage. It mainly deals with the using of Road Economic Decision (RED) model, in which Highway Development and Management (HDM)-4 VOC model (Version 3.2) is used for computing coefficient of Vehicle Operating Cost (VOC) and RED Main Economic Decision model is used to compute value of International Roughness Index (IRI) for optimum maintenance strategy for strategic road network of Nepal with low traffic volume. The outcome of analysis will help the concern authority to make good decision on making priority and economical selection of maintenance strategy for the road having specified range of IRI value depending on the pavement type, surface type and volume of vehicle with spatial coverage.
\end{abstract}

Keywords: IRI, maintenance, pavement, RED, VOC

\section{Introduction}

Road network is one of the main infrastructures of transportation. Rural roads (low volume roads) have great importance in Nepal because about $85 \%$ of the people live in the rural area and most of them are still deprived from access to many essential facilities like education, health, market and electricity etc (International Fund for Agricultural, 2013). Thus, an adequate road infrastructure network is essential for economic growth and continuous road investment is necessary for the development and maintenance of road network. By proper maintenance of roads continuous acceptability is achieved as well as higher economy, safety and serviceability are gained. Planned Maintenance is systematic and efficient application of routine, preserve the road

*Corresponding author: Ramesh Bala

Department of Civil Engineering, Khwopa College of

Engineering, Libali-8, Bhaktapur, Nepal

Email: rameshbala.2043@gmail.com

(Received: 2016 Sept 09 Accepted: 2016 Dec 15) asset and provide desired level of service to the traveling public. Maintenance helps in reducing deterioration, lowering vehicle operating costs, keeping the road open, ensuring safety and minimizing environmental issues.

Roughness is an important indicator of pavement riding comfort and safety $(\mathrm{Hu}, 2004)$. From an auto driver's point of view, rough roads mean discomfort, decreased speed, potential vehicle damage, and increased operating cost (Hossain, 2000). Therefore, surface roughness is a condition indicator and is the main factor affecting vehicle operating costs and hence serviceability that should be carefully considered when evaluating primary pavements (Hu, 2004). There are various method of evaluating pavement roughness; IRI is also one of them. IRI is the roughness index most commonly obtained from measured longitudinal road profiles. It is calculated using a quarter-car vehicle math model, whose response is accumulated to yield a roughness index 
with units of slope (in/mi, m/km, etc.) (Michal W: Sayers, 1986). Fig 1 shows the IRI roughness scale

Fig 1 IRI Roughness Scale (Michal W: Sayers,

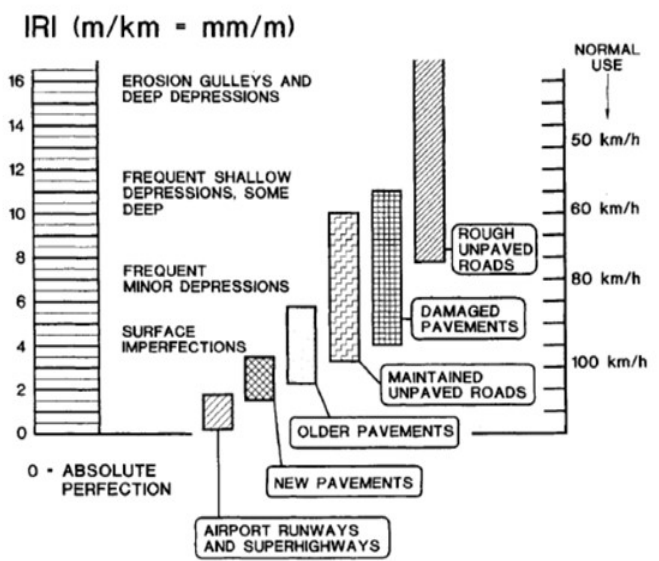

1986)

For the analysis of data RED model is used. RED Model is developed by Road Management Initiative (RMI), a key component of the Sub-Saharan Africa Transport Policy Program (SSATP), which is a collaborative framework set up to improve transport policies and strengthen institutional capacity in the African region so as to improve the decision-making process for the development and maintenance of low-volume rural roads (Callo, 2010). RED model performs the economic evaluation of improvements and maintenance projects adopting the consumer surplus approach, which measures the benefits to road users and consumers of reduced transport costs (Callo, 2010). This model is customized for low-volume unpaved roads, with traffic volumes between around 50 and 300 vehicles per day, to fulfill the planning and programming needs of highways agencies in charge of low-volume roads presenting the results in a practical and effective manner (Archondo-Callao, 2004).

RED HDM-4 VOC module Version 3.2 requires following basic input parameters:

1. Country/Region, Year

2. Terrain Type

3. Road Type

4. Road Characteristics
5. Vehicle Type

6. Vehicle Fleet Characteristics

7. Currency Name, and Exchange Rate divider to US \$.

8. Reference vehicle

For the computation of VOC coefficient, data related to terrain type i.e. rise and fall $(\mathrm{m} / \mathrm{km})$ and horizontal curvature $(\mathrm{deg} / \mathrm{km})$ of the selected road is computed with the help of Google Earth. Vehicle fleet characteristics were surveyed in the local market in the year 2013 as well as Sector Wide Road Programme (SWRP) and Priority Investment Plan (PIP) Report 2007 data was used considering inflation rate reported by Nepal Rastra Bank. Car medium is considered as reference vehicle adopted to estimate roughness as a function of speed of reference vehicle.

The process of computing the vertical and horizontal profile of road is shown below: (Callo, 2010)

Vertical Profile

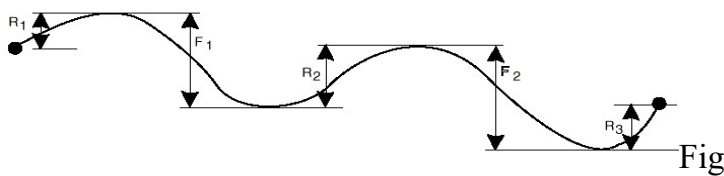

Fig 2 Vertical Profile

Rise plus Fall $=\left(\mathrm{R}_{1}+\mathrm{R}_{2}+\mathrm{R}_{3}+\mathrm{F}_{1}+\mathrm{F}_{2}\right) /$ Length $(\mathrm{m} / \mathrm{km})$

Horizontal Profile

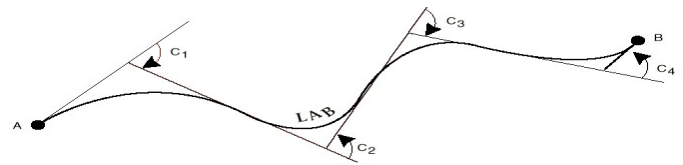

Fig 3 Horizontal Profile

Horizontal Curvature $=\left(\mathrm{C}_{1}+\mathrm{C}_{2}+\mathrm{C}_{3}+\mathrm{C}_{4}\right) /$ Length $(\mathrm{deg} / \mathrm{km})$

The main objective of the paper is to compute the IRI value by using RED model for the carrying out the optimum maintenance work for low volume road network.

\section{Data Collection}

DoR is the main source of data collection. Google Earth was used for surveying to compute the terrain data. Similarly, the vehicle fleet characteristics data were collected from Nepal Automobile Dealers 
Association (NADA) and SWRP and PIP Report 2007 of Nepal government and market survey.

The raw data collected from DoR contain both of national highway and feeder road among six road links with low traffic volume (i.e. 50 - 300 Average Annual Daily Traffic (AADT) excluding motor cycle and non-motorized vehicle) with Surface Treatment with Granular Base (STGB) as pavement type, selected randomly from all over the country. The roads considered for carrying out the research work is shown in Table below:

Table 1 Inventory of Road under study

\begin{tabular}{|c|c|l|c|c|c|c|c|}
\hline Code & Link No. & \multicolumn{1}{|c|}{ Road } & AADT & $\begin{array}{c}\text { AADT } \\
\text { excl. MC } \\
\text { Rickshaw }\end{array}$ & $\begin{array}{c}\text { AADT } \\
\text { in PCU }\end{array}$ & $\begin{array}{c}\text { Pavement } \\
\text { type }\end{array}$ & $\begin{array}{c}\text { Actual } \\
\text { Length } \\
\text { (IRI) }\end{array}$ \\
\hline 21 & F01102 & Gorusinge-Patharkot & 637 & 296 & 743 & & 11.01 \\
\hline 34 & F01401 & Pyuthan-Chakchake & 188 & 88 & 207 & & 25 \\
\cline { 1 - 5 } \cline { 5 - 6 } & F04004 & Basantapur-Tehrathum & 224 & 181 & 326 & \multirow{2}{*}{ STGB } & 2 \\
\hline 111 & F04206 & Baglung-Myagdi district border & 234 & 169 & 227 & & 1.63 \\
\hline 127 & F04801 & Surkhet-Dailekh district border & 296 & 174 & 400 & & 23 \\
\hline 153 & F05203 & Katari-Harkapur (Sunkoshi) & 324 & 238 & 512 & & 49 \\
\hline
\end{tabular}

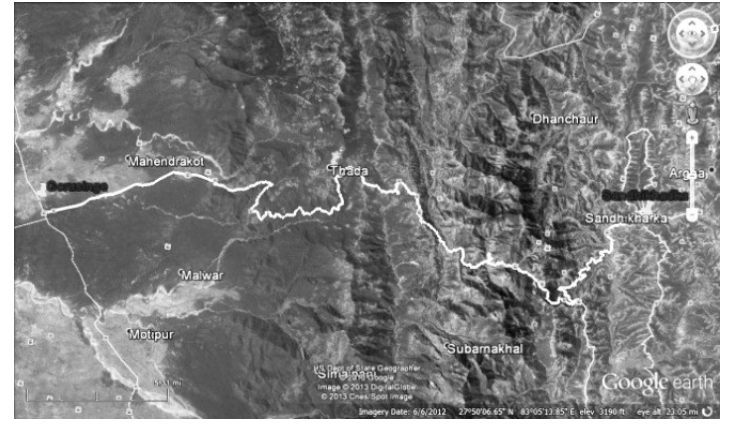

4 (a) Gorusinge-Patharkot Road

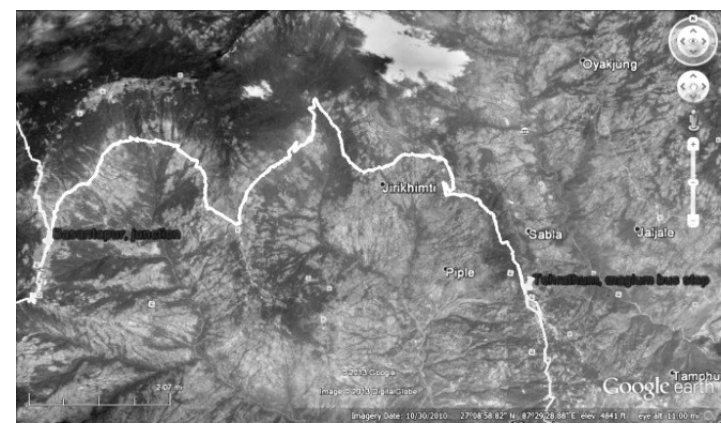

4 (c) Basantapur-Tehrathum Road

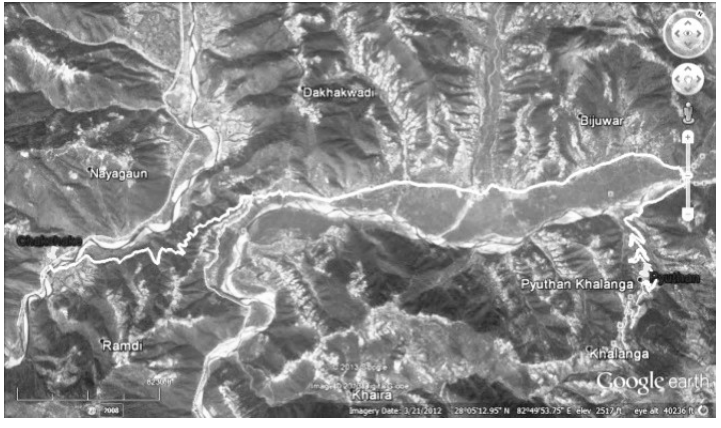

4 (b) Pyuthan-Chakchake Road

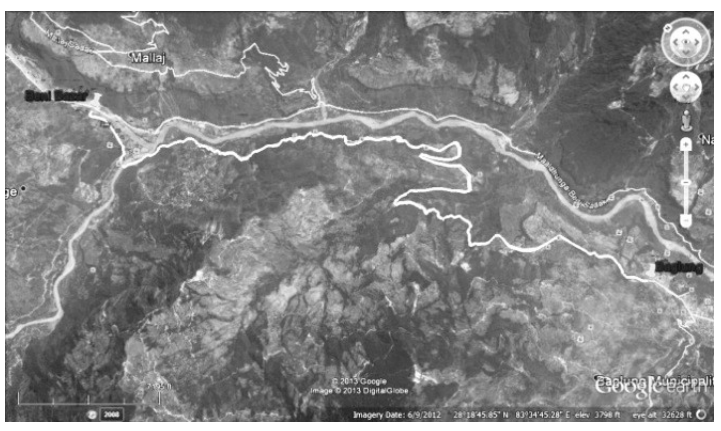

4 (d) Baglung-Myagdi district border Road 


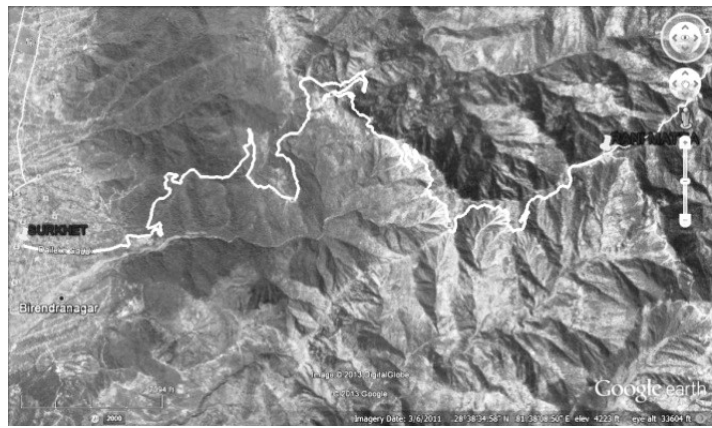

4 (e) Surkhet-Dailekh district border Road

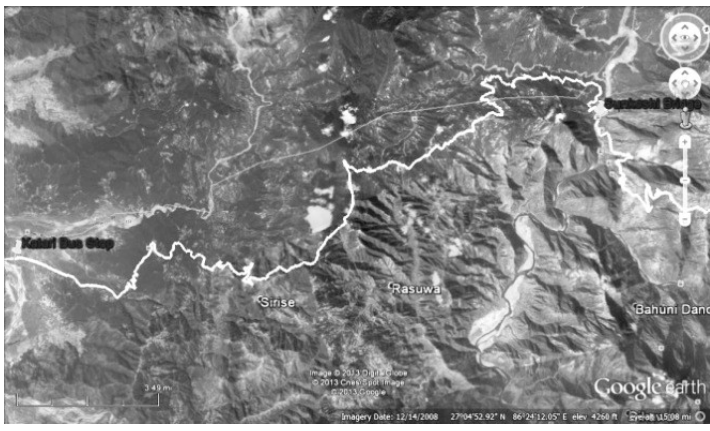

4 (f) Katari - Harkapur Road

Fig 4 Profile of road under study in Google Earth, 2013

Table 2 Summary of Survey Data of Road from Google Earth, 2013

\begin{tabular}{|c|c|c|c|c|c|c|}
\hline SN. & Road & $\begin{array}{c}\text { Road Length } \\
\text { Considered } \\
(\mathrm{Km})\end{array}$ & $\begin{array}{c}\text { Total Sum of } \\
\text { Rise and Fall } \\
(\mathrm{m})\end{array}$ & $\begin{array}{c}\text { Rise and } \\
\text { Fall } \\
(\mathrm{m} / \mathrm{Km})\end{array}$ & $\begin{array}{c}\text { Total } \\
\text { Horizontal } \\
\text { Angle }(\mathrm{deg})\end{array}$ & $\begin{array}{c}\text { Horizontal } \\
\text { Curvature } \\
(\mathrm{deg} / \mathrm{Km})\end{array}$ \\
\hline 1 & Gorusinge-Patharkot & 68 & 7684.92 & 113.014 & 49015 & 720.81 \\
\hline 2 & Pyuthan-Chakchake & 20.8 & 2793.8 & 134.317 & 10713 & 515.05 \\
\hline 3 & Basantapur-Tehrathum & 25.41 & 4062.98 & 159.897 & 18105 & 712.51 \\
\hline 4 & Baglung-Myagdi district border & 14.99 & 2085.14 & 139.102 & 9530 & 635.76 \\
\hline 5 & Surkhet-Dailekh district border & 21.15 & 3330.55 & 157.473 & 15815 & 747.75 \\
\hline 6 & Katari-Harkapur (Sunkoshi) & 47.18 & 6358.43 & 134.77 & 43570 & 923.48 \\
\hline
\end{tabular}

\section{Methodology}

\subsection{Computation of Coefficient of Vehicle Operating Cost}

\section{Input Parameter}

Country/ region, Terrain type, Evaluation Year, Road characteristics, Currency name. Road type, Vehicle types. Vehicle fleet characteristics. Reference vehicle and exchange rate divider to US S.

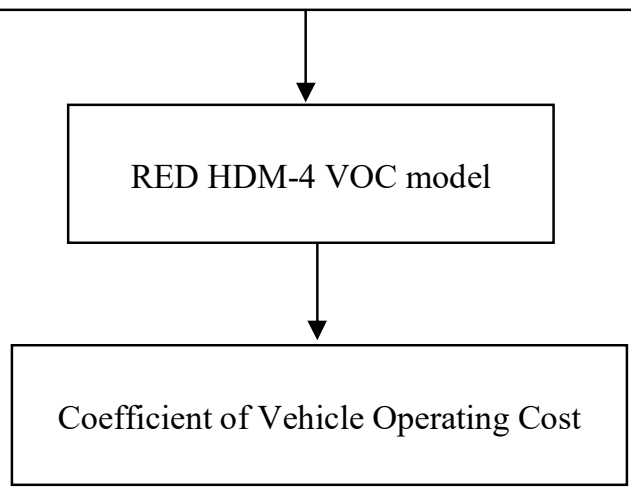

Fig 5 Methodology of computing of VOC coefficient 


\subsection{Computation of IRI value}

IRI value is computed by using RED main model

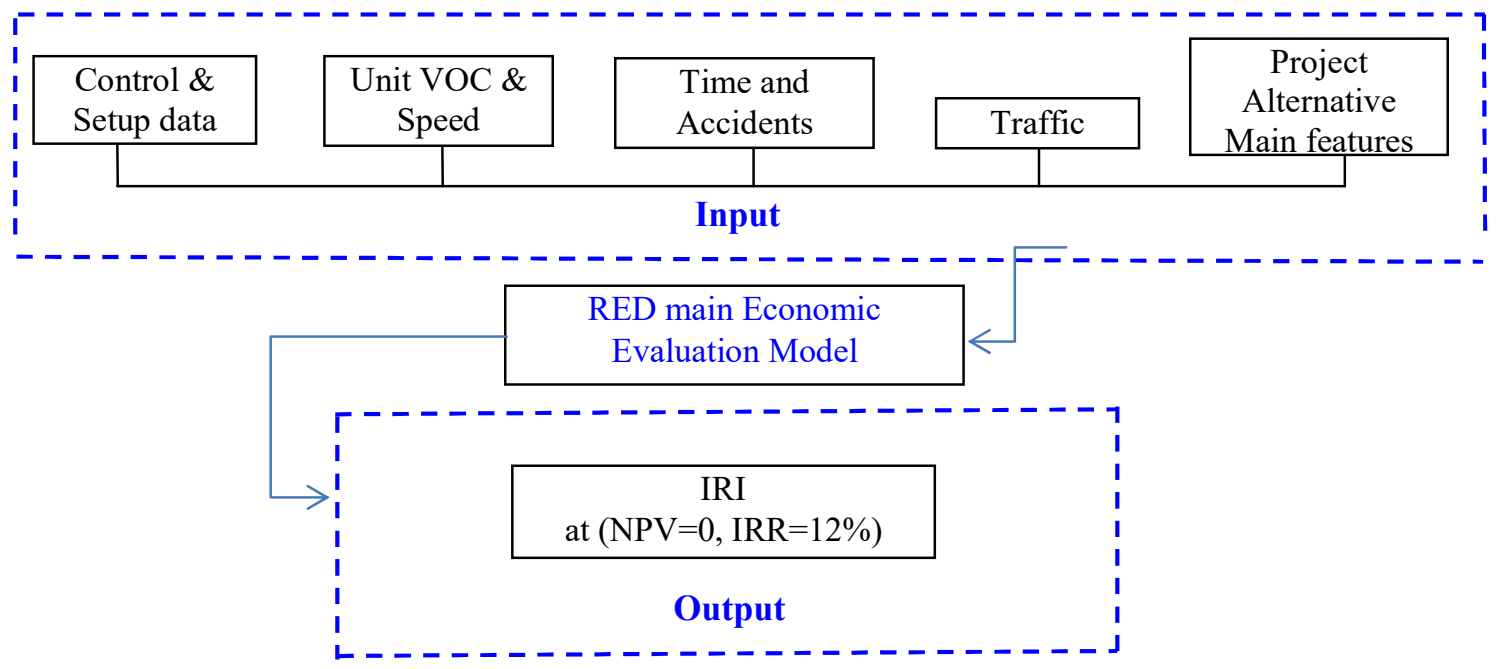

Fig 6 Methodology of computing of IRI Value

The unit vehicle operating cost $(\$ / \mathrm{veh}-\mathrm{km})$ and speeds of vehicles $(\mathrm{km} / \mathrm{hr})$ are the function of roughness represented in the following expression. (Archondo-Callao, 2004)

VOC $=\mathrm{a} 0+\mathrm{a} 1 * I R I+\mathrm{a} 2 * \mathrm{IRI}^{2}+\mathrm{a} 3 * \mathrm{IRI}^{3}$

where, a0, a1, a2, a3 are coefficient of roughness calculated by HDM- 4 VOC model

Speed $=b 0+b 1 * I R I+b 2 * I R I^{2}+b 3 * I R I^{3}$

where, b0, b1, b2, b3 are coefficient of roughness calculated by HDM- 4 VOC model. Time and accident data were considered as default value of the model.

Traffic data were assigned from the traffic data obtained from DoR for each road.

For the Project Alternative, Main Features, the financial investment cost was assigned the construction cost analyzed for each road considered. similarly, fixed financial maintenance cost was computed from annual maintenance expenditure allocated by DoR. The computed financial investment cost and annual maintenance expenditure are shown in table below:
Table 3 Financial Investment Cost

\begin{tabular}{|c|c|l|c|c|c|}
\hline S.N & Link No. & \multicolumn{1}{|c|}{ Road } & $\begin{array}{c}\text { Cost of } \\
\text { DBSD (\$) }\end{array}$ & $\begin{array}{c}\text { Cost of } \\
\text { Drain (\$) }\end{array}$ & $\begin{array}{c}\text { Total Cost } \\
\text { (DBSD) (\$) }\end{array}$ \\
\hline 1 & F01102 & Gorusinge-Patharkot & 75691.33 & 31212.25 & 106903.58 \\
\hline 2 & F01401 & Pyuthan-Chakchake & 57732.64 & 31212.25 & 88944.89 \\
\hline 3 & F04004 & Basantapur-Tehrathum & 69705.10 & 31212.25 & 100917.35 \\
\hline 4 & F04206 & Baglung - Beni Road & 60725.75 & 31212.25 & 91938.01 \\
\hline 5 & F04801 & $\begin{array}{l}\text { Surkhet-Dailekh district } \\
\text { border }\end{array}$ & 59378.85 & 31212.25 & 90591.11 \\
\hline 6 & F05203 & $\begin{array}{l}\text { Katari-Harkapur } \\
\text { (Sunkoshi Bridge) }\end{array}$ & 60725.75 & 31212.25 & 91938.01 \\
\hline
\end{tabular}

Table 4 Annual Maintenance Expenditure

\begin{tabular}{|c|c|c|c|}
\hline Average Inflation Rate as per NRB & 9.5 & & \\
\hline No. of year: & 1.0 & $\mathrm{P}(\mathrm{F} / \mathrm{P}, \mathrm{i} \%, \mathrm{~N})$ & 1.095 \\
\hline \multicolumn{4}{|l|}{ Argakhachi Rate 2013/2014 } \\
\hline \multirow{2}{*}{ Expenditure Category } & 2012 & 2013 & Remarks \\
\hline & $\mathrm{Rs} / \mathrm{Km} / \mathrm{year}$ & Rs/Km/year & \\
\hline Routine Maintenance & 35000 & 38325 & \\
\hline Recurrent Maintenance & 73000 & 79935 & \\
\hline Specific Maintenance & 100000 & 109500 & \\
\hline Traffic Safety & 9000 & 9855 & \\
\hline Bio Engineering & 1000 & 1095 & \\
\hline Emergency Maintenance Work & 18000 & 19710 & \\
\hline Damage Rehabilitation Works & 8000 & 8760 & \\
\hline Equipment Maintenance and Mobilization & 3500 & 3832.5 & \\
\hline
\end{tabular}

\section{Results}

With the help of RED Main Model, IRI value for the road link considered were found to be as mention in table 5 . The value obtained indicates the poor riding quality of road. As per Roughness Scale shown in Fig 1 such road surface is characterized as frequent minor depression with some shallow and deep depression. With the help of RED HDM-4 VOC Model VOC and Speed can be interpreted as function of IRI. 
Table 5 Computed IRI of Road Link Considered

\begin{tabular}{|c|c|c|c|c|c|c|}
\hline Road & F04004 & F05203 & F01102 & F04206 & 4801.00 & F01401 \\
\hline IRI & 8.04 & 9.88 & 10.06 & 7.64 & 6.88 & 6.13 \\
\hline
\end{tabular}

\begin{tabular}{|l|l|}
\hline Average IRI & $\mathbf{8 . 1 0}$ \\
\hline
\end{tabular}

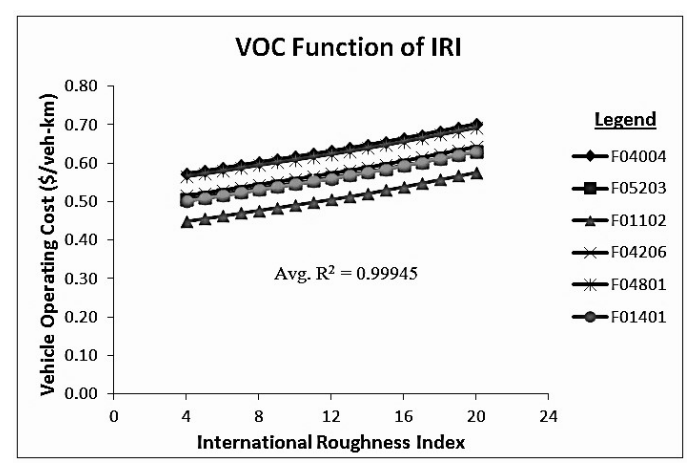

Fig 7 VOC Function of IRI for Average Vehicle Fleet

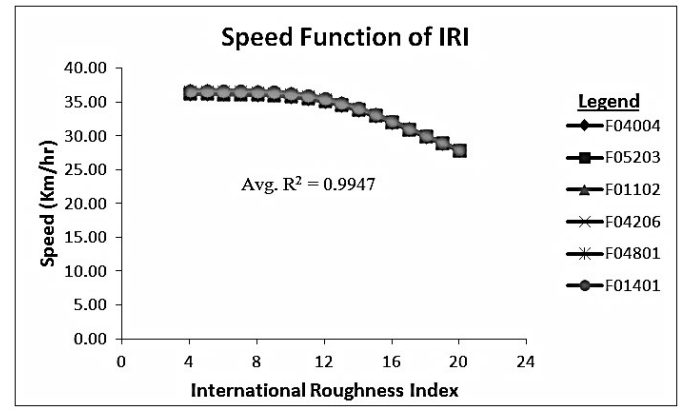

Fig 8 Speed Function of IRI for Average Vehicle

Fleet

\section{Conclusion}

The proposed work is to determine the value of IRI for optimum maintenance work for low volume road of our country. With the help of RED Model, IRI value for optimum maintenance work was found out to be 8.1 i.e. according to our maintenance strategy, for the optimization of maintenance work for low volume traffic Road, periodic maintenance should be applied when the IRI value of Road link reach to 8.1. The result obtained indicates the poor riding quality of road. Providence of good riding quality requires frequent maintenance activities which may result high maintenance cost and may become uneconomical for low traffic volume roads, even though maintaining the riding quality depends upon the policy of the government upon which maintenance cost depends. From the graph of VOC function of IRI, vehicle operating cost increases with increase in IRI. Similarly, from the graph of Speed function of IRI, speed decrease as the value of IRI increases.

\section{References}

[1] Archondo-Callao, R. (2004). The Roads Economic Decision Model (RED) for the Economic Evaluation of Low Volume Roads. SSATP Working paper No. 78 .

[2] Callo, R. A. (2010). HDM-4 Road Use Costs Model Version 2. Washington D.C: The World Bank.

[3] Hossain, J. H. (2000). An Update on Kansas' Experience with PCCP Smoothness Specifications and Incentives. MID-Continent Transportation Symposium 2000 Proceedings .

[4] Hu, F. (2004). Development of a direct type road roughness evaluation system. Scholar Commons .

[5] International Fund for Agricultural. (2013, July). Retrieved March 30, 2016, from www.ifad.org: https://www.ifad.org/documents/10180/c3f05a7f-627b40a6-8bce-c3330c9849dc

[6] Michal W: Sayers, T. D. (1986). Guidelines for Conducting and Calibrating Road Roughness. World Bank Technical Paper Number 46 . 